\title{
The Presence-Absence Situation and Its Impact on the Assemblage Structure and Interspecific Relations of Pronophilina Butterflies in the Venezuelan Andes (Lepidoptera: Nymphalidae)
}

\author{
TW Pyrcz ${ }^{1}$, R GARLACZ $^{1}$ \\ Zoological Museum, Jagiellonian University, Kraków, Poland
}

\section{Keywords}

Altitudinal gradients, Cordillera de Merida, niche partitioning, parapatric distribution, signal jamming, spatial interference

\section{Correspondence}

Tomasz W Pyrcz, Zoological Museum, Jagiellonian University, Ingardena 6, 30-060 Kraków, Poland; tomasz.pyrcz@uj.edu.pl

Edited by André V Freitas - UNICAMP

Received 15 September 2011 and accepted 19 March 2012

Published online 4 May 2012

(C) The Author(s) 2012. This article is published with open access at Springerlink.com

\begin{abstract}
Assemblage structure and altitudinal patterns of Pronophilina, a species-rich group of Andean butterflies, are compared in El Baho and Monte Zerpa, two closely situated and ecologically similar Andean localities. Their faunas differ only by the absence of Pedaliodes ornata Grose-Smith in El Baho. There are, however, important structural differences between the two Pronophilina assemblages. Whereas there are five co-dominant species in Monte Zerpa, including $P$. ornata, Pedaliodes minabilis Pyrcz is the only dominant with more than half of all the individuals in the sample in El Baho. The absence of $P$. ornata in El Baho is investigated from historical, geographic, and ecological perspectives exploring the factors responsible for its possible extinction including climate change, mass dying out of host plants, and competitive exclusion. Although competitive exclusion between $P$. ornata and $P$. minabilis is a plausible mechanism, considered that their ecological niches overlap, which suggests a limiting influence on each other's populations, the object of competition was not identified, and the reason of the absence of $P$. ornata in El Baho could not be established. The role of spatial interference related to imperfect sexual behavioral isolation is evaluated in maintaining the parapatric altitudinal distributions of three pairs of phenotypically similar and related species of Pedaliodes, Corades, and Lymanopoda.
\end{abstract}

\section{Introduction}

In depth analysis of local butterfly assemblages structure, particularly in montane areas is often hampered by the lack of statistically workable data sets only moderately biased by sampling methods. From this perspective, the subtribe Pronophilina (Nymphalidae, Satyrinae) sensu Lamas et al (2004) is a particularly suitable group for studies on population ecology. It is highly diverse, constituting an overwhelming majority in terms of species richness and abundance in some high elevation areas of the northern Andes (Adams 1985). Most species are distributed in narrow elevational belts. Data on their abundance and relative frequencies are easy to obtain with standard sampling procedures (Pyrcz \& Wojtusiak 2002, Pyrcz \& Viloria 2007, Pyrcz et al 2009a, Mahecha Jimenez et al 2011). Pronophilina adults are easy to locate in the field as they are always associated with their larval host plants, common Andean bamboos of the genus Chusquea (DeVries 1987, Greeney et al 2009, 2010).

Synchronic occurrence of several phenotypically similar species of Pronophilina in the same habitat using the same resources suggests the possibility of competition. When the ecological niches of two, usually closely related species overlap, competitive exclusion is likely to occur leading to either the exclusive dominance of one of the two species or to coexistence (Rodríguez 2001, Juliano et al 2004). The theory of competitive exclusion first formulated by Gause 
(1934) is currently widely applied in ecology and well supported mathematically (Feng 1997, Mougi \& Nishimura $2005)$ but rarely observed in natural ecosystems (Bengtsson 1989, Shapiro 1992). In 1996, a study of faunas and altitudinal distribution patterns of the Pronophilina was carried out in Monte Zerpa in the Venezuelan Cordillera de Mérida (Pyrcz \& Wojtusiak 2002). A similar project, in scope and methods, was conducted exactly 10 years later in El Baho, a site situated in the same mountain range. The only notable difference at the species level between the two samples appeared to be the absence of one of the co-dominant species in El Baho. This finding raised two issues: How does the absence of this species affect Pronophilina assemblage structure in El Baho compared with Monte Zerpa, and what are the possible factors responsible for its absence in El Baho.

The distribution of Pronophilina species in well-defined elevational belts and the occurrence of pairs of related and/or similar species apparently replacing each other in altitude were first explored by Adams (1985) and more thoroughly investigated by Pyrcz et al (2009b). Adams was unable to propose an ecological mechanism responsible for maintaining altitudinal parapatric distributions. Pyrcz \& Wojtusiak (2002) suggested "spatial interference" as an explanation, a mechanism somewhat related to mating interference (Feng 1997) and signal jamming (Thornhill \& Alcock 1983). Mating interference and signal jamming are both interspecific interactions occurring during mate selection and that might adversely affect the fitness of one or both species involved and that is caused by incomplete species recognition (Gröning \& Hochkirch 2008). The sampling in Monte Zerpa and El Baho provided an opportunity for testing this hypothesis.

\section{Material and Methods}

\section{Study area}

This study compared the cloud forest butterfly fauna of Monte Zerpa and El Baho, two sites located in the Venezuelan Cordillera de Mérida (CM), an isolated mountain range separated from the main Andes by the Táchira depression.

El Baho and Monte Zerpa are $50 \mathrm{~km}$ apart as a crow flies. El Baho is in the upper Santo Domingo valley $\left(8^{\circ} 50^{\prime} \mathrm{N}\right.$; $70^{\circ} 42^{\prime} \mathrm{W}$ ), isolated from other cloud forest areas of the CM by the Serranía de Santo Domingo from the south, the Niquitao massif from the west, the Calderas massif from the north, and by the narrow and deep gorge of the Santo Domingo river from the east (Fig 1). Monte Zerpa is located in the upper Chama Valley $\left(8^{\circ} 40^{\prime} \mathrm{N} ; 71^{\circ} 8^{\prime} \mathrm{W}\right)$, separated from other cloud forests of the $\mathrm{CM}$ by high mountain ridges of the Serranía de la Culata from the north and the
Sierra Nevada from the south, and the Ejido desert from the southwest, an area of xeric vegetation at the lower part of the valley of Chama at 700-1,300 $\mathrm{m}$ asl. Palynological and geological sources indicate that the Chama Valley has been isolated since the Pleistocene (Schubert \& Vivas 1993). The lowest point separating the valleys of Santo Domingo and Chama is the Mucubají pass at 3,600 $\mathrm{m}$ asl. Cloud forests covering mid-elevations of both valleys are isolated by desert páramo above 3,200 $\mathrm{m}$ asl in the CM. The climate (rainfall, mean temperatures) of the two sites is similar (Veillon 1989), although daily temperature patterns show slight differences due to northwest exposure of the slope in El Baho, compared with southeast exposure of Monte Zerpa.

\section{Methods}

Adult Pronophilina were sampled in El Baho along an elevational transect spanning from 2,450-3,100 $\mathrm{m}$ asl and extending from mid-elevation cloud forest to subparamo, a patchy habitat composed of isolated stands of tall Swallenchloa bamboos, Ericaceae shrubs, and scrubland ("pajonal") dominated by Poaceae and Asteraceae (Espeletia). Butterflies were collected with standard entomological nets and in Rydon-Van Someren traps placed every $50 \mathrm{~m}$ in elevation. Each trap was baited with dog dung, which is a very effective attractant for adult Pronophilina butterflies (Pyrcz \& Wojtusiak 2002). Each trap was checked six times in the space of 10 days. Every butterfly collected in the trap was placed in an envelope marked with the date and elevation. Sampling took place in November, which is the late rainy season in the CM. Altitude and temperature were measured every $200 \mathrm{~m}$ between 2,350 and 3,050 $\mathrm{m}$ and between the hours of 09.00-15.00 every 2 days with a Silva multifunction tool.

Data from El Baho were compared with data gathered in Monte Zerpa in 1996 during a study employing similar sampling methods. Some data from Monte Zerpa were published and discussed by Pyrcz \& Wojtusiak (2002) but others remained unpublished. The Monte Zerpa transect spans $800 \mathrm{~m}$ in altitude, from 2,250-3,050 m, and extends from mid-elevation cloud forest to dense elfin forest dominated by Clusia trees and Chusquea bamboos.

All the individuals were identified to subspecies in the Zoological Museum of the Jagiellonian University (Kraków, Poland), which holds the largest World collection of Pronophilina, including a large-type data base containing photographs and genital dissections of types. Standard taxonomical methods were used. In particular, male and female genitalia dissections were made by soaking abdomens in warm $10 \% \mathrm{KOH}$ solution. Genital parts were preserved in glycerol vials. Male androconia were studied through luminescent light. 
Fig 1 Study sites and distribution of Pedaliodes ornata in the Cordillera de Mérida (1: Pedaliodes ornata ornata; 2: Pedaliodes ornata haroldboxi; black area: land above 3,000 $\mathrm{m}$ asl, dark grey area: land above $2,000 \mathrm{~m}$ asl).



Distributional (altitudinal and geographic) patterns of all species reported from El Baho and Monte Zerpa were examined based on data gathered throughout the CM by the senior author between 1992 and 2010. Some of the distributional data were published in a series of taxonomical and zoogeographical papers (Viloria et al 2003, Pyrcz 2007, Pyrcz \& Viloria 2009, Pyrcz et al 2009a, 2010), whereas others remain unpublished. A special attention was given to three species of Pedaliodes: $P$. ornata Grose-Smith, P. minabilis Pyrcz, and Pedaliodes montagna Adams \& Bernard (Fig 2). Pedaliodes ornata is an endemic species in the CM with a disjunctive distribution (Fig 1). It was recorded in two areas. The nominate subspecies occurs in the valley of Chama in the central part of the range and on the Lago de Maracaibo slopes of the La Culata. Pedaliodes ornata haroldboxi Pyrcz \& Viloria is found only in the Pico Tonojo massif in the northern CM. Pedaliodes minabilis, previously confused with $P$. ferratilis Butler (Adams \& Bernard 1981), is also an endemic species of the CM. It is found throughout the range, including the Chama and Santo Domingo valleys. The Chama valley population is characterized by a uniform HWV color pattern. The other form, Pedaliodes minabilis f. luteocosta, has a yellow HWV costal streak and is rare in the Chama valley but predominates elsewhere (all but two specimens in $\mathrm{El}$ Baho). Pedaliodes montagna, described originally from the $\mathrm{CM}$, has since been found to be widely distributed in the Andes (Pyrcz 2004). Pedaliodes montagna and P. minabilis are similar in size and color patterns; they are both predominantly dark-brown-patterned on the upper and underside. Sexual dimorphism in $P$. minabilis, $P$. montagna, and $P$. ornata is slight and expressed only in the slightly larger size of the females.
A list of all the species recorded in El Baho and Monte Zerpa was compiled. The Sørensen index was used to assess similarity at the species and subspecies level. A statistical analysis of the data set composed of trapped individuals was performed. Shannon $\left(\mathrm{H}^{\prime}\right)$ and Simpson (D) diversity measures, Berger-Parker index of dominance and evenness measure, and Fisher's Alpha index of diversity were calculated for the two transects. Proportions of $P$. minabilis and $P$. ornata in the samples were calculated. Distribution patterns along altitude for $P$. minabilis and $P$. montagna, Lymanopoda obsoleta Westwood and Lymanopoda dietzi Adams \& Bernard, and Corades chelonis Hewitson and Corades pax Watkins were measured. Spearman correlation ( $\left.S_{\text {corr }}\right)$ was computed to correlate altitudinal distribution patterns of the above species with each other. Relative abundance of $P$. minabilis and $P$. ornata were calculated. Non-parametric species-richness estimators were considered uninformative and were not used because the samples represent complete faunal inventories (an assumption based on the knowledge of distributional patterns of Pronophilina in the CM). Statistical analysis was carried out with the Statistica 6.0 software package (Tulsa, USA) and Species Diversity and Richness III software (Pisces Conservation).

\section{Results}

Fauna

A total of 22 species were collected in baited traps along the elevational transect in El Baho (see Online supplementary material). Additionally, four species, Lymanopoda 
Fig 2 Male adults of Pedaliodes ornata, Pedaliodes minabilis, and Pedaliodes montagna. 1. Pedaliodes ornata haroldboxi, Pico Tonojo, 2. Pedaliodes ornata ornata, Monte Zerpa, 3. Pedaliodes minabilis, Monte Zerpa, 4. Pedaliodes minabilis, El Baho (form luteocosta), 5 . Pedaliodes montagna, Monte Zerpa, 6. Pedaliodes montagna, El Baho.
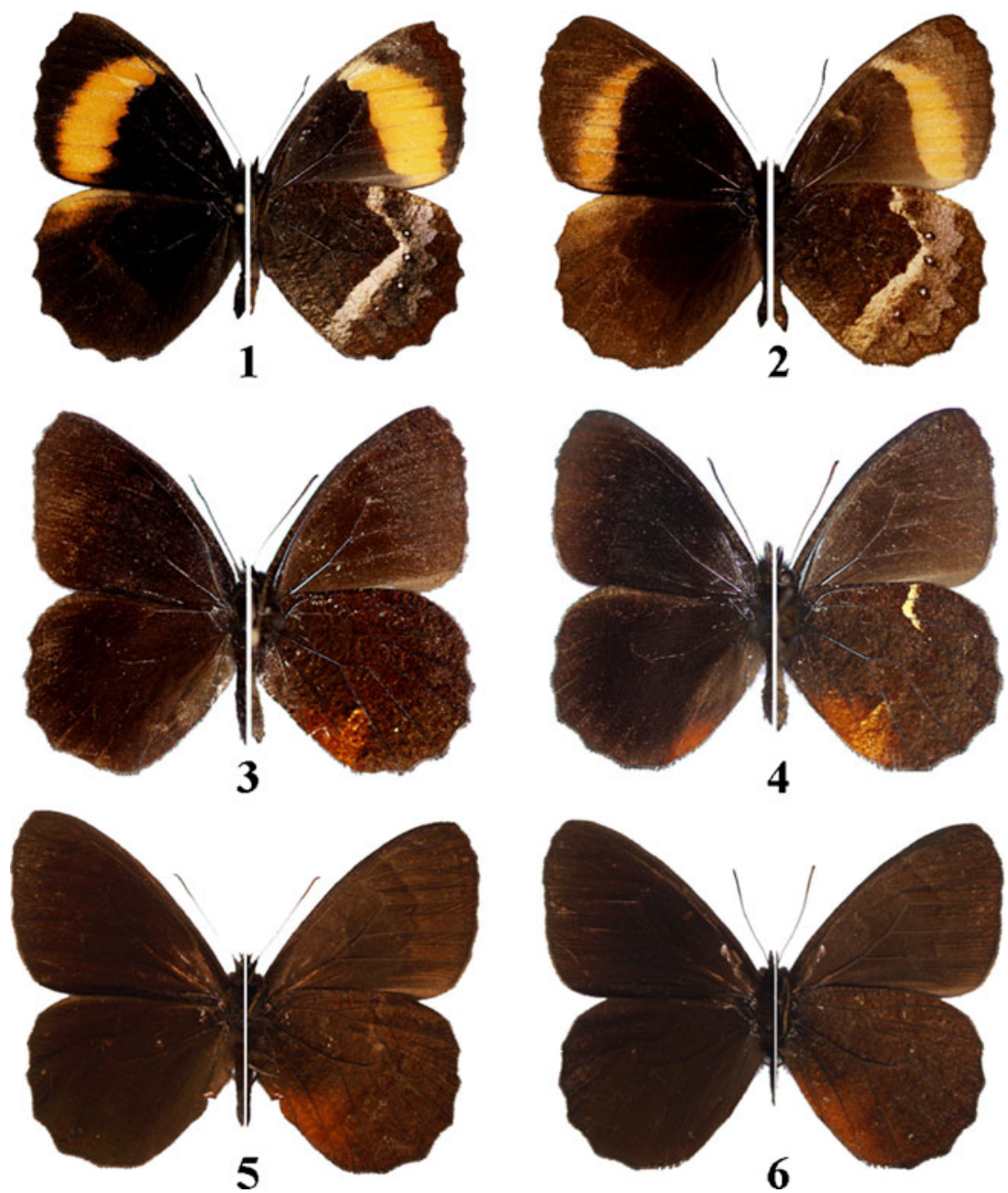

albocincta, Pedaliodes proerna, Pedaliodes japhleta Butler, and Corades pannonia Hewitson were collected exclusively in hand nets at 2,300-2,400 $\mathrm{m}$ and one, Manerebia franciscae (Adams \& Bernard), at 2,550 m asl. In Monte Zerpa, 22 species were also collected on baits along the transect (see Online supplementary material). Three species, Lymanopoda marianna Staudinger, Steromapedaliodes albonotata (Godman), and Cheimas opalinus (Staudinger), were caught in hand nets at 3,100 $\mathrm{m}$ asl. The only species reported in Monte Zerpa and not found in El Baho was $P$. ornata. Its absence is not an artifact of the sampling method used, as the elevation belt where it occurs $(2,400-$ 2,900 $\mathrm{m}$ asl) was extensively sampled in El Baho with both baited traps and hand nets before and after this study during different seasons of the year. Sørensen similarity index between El Baho and Monte Zerpa is 0.74 at the species level for trapped species and 0.96 when species collected with hand nets were included. At the subspecies level, the Sørensen similarity index is $\mathbf{0 . 5 5}$. The latter lower value reflects a wide scale differentiation of the Pronophilina of the $\mathrm{CM}$ at high elevations (above $2,800 \mathrm{~m}$ asl), which has led to the evolution of several sub-centers of endemism throughout the range. Six species, including four paramo and subparamo specialists, were represented in El Baho and Monte Zerpa by different subspecies: C. opalinus, L. marianna, S. albonotata, L. dietzi, Lasiophila zapatoza (Westwood), and Pedaliodes plotina (Hewitson).

\section{Diversity and assemblage structure}

In El Baho, 543 individuals were collected in baited traps over six sampling days (ca. 90 per day) compared with 943 individuals in Monte Zerpa over 20 days (ca. 47 per day). Sampling took place in the dry season in Monte Zerpa and in the wet season in El Baho. Although Pronophilina phenology has not been rigorously studied so far, our experience in the field indicates that abundance is higher during dry season, but there are few differences in seasonal species composition and species relative abundance. Most seasonal species belong to the genus Manerebia and to paramo denizens. Diversity in both Monte Zerpa and El Baho is low. Particularly in El Baho, the Shannon index indicates an overall value below 2 and along the 
transect values below 2 at 13 from among 15 elevational stations except for the lowest two at 2,400 and 2,450 m asl (Table 1). There is a negative correlation between species richness and elevation in El Baho $\left(S_{\text {corr }}=-0.54, P<\right.$ $0.003)$, but there is no correlation between diversity $(\mathrm{H})$ and elevation $\left(S_{\text {corr }}=0.26, P>0.34\right)$. In Monte Zerpa, the Shannon diversity index indicates slightly higher values at all elevational stations. The overall Shannon index is higher in Monte Zerpa, but the Fisher Alpha and Simpson indices are lower (Table 2). The Berger-Parker dominance index is very low in both sites but particularly so in El Baho. In both Monte Zerpa and El Baho, species abundance agrees with log series model (EB, $P=0.13$; $M Z, P=0.07$ ), which justifies the use of Fisher Alpha as the most appropriate measure of diversity. Moreover, the "broken stick model" fitted only for Monte Zerpa sample $(P=0.81)$ showing structural difference in comparison with El Baho sample $(P=0.01)$ and agrees with the observed higher evenness in Monte Zerpa.

At the assemblage level, the most notable differences are the dominance of $P$. minabilis in the El Baho sample ( $53 \%$ overall and $>60 \%$ of the sample at seven elevations) and the absence of $P$. ornata in El Baho, one of the codominant species in Monte Zerpa (Table 3). In Monte Zerpa, $P$. minabilis $+P$. ornata are co-dominant species at 2,800-3,000 $\mathrm{m}$ asl (Table 4). In El Baho, the second most abundant species is $C$. pax (10.4\%), the only other one with more than $10 \%$ in the sample. The second most abundant species of Pedaliodes in El Baho is P. montagna represented by $7 \%$. In Monte Zerpa, P. montagna (17\%) is the most abundant species (Table 5). It is the dominant species in the Pedaliodes community at lower elevations (below $2,500 \mathrm{~m})$. Pedaliodes montagna also occurs at lower elevations (below 2,600 $\mathrm{m}$ asl) in El Baho. Pedaliodes minabilis is the third most abundant species in Monte Zerpa.

\section{Altitudinal patterns}

In El Baho, several species occur some 150-200 m lower than in Monte Zerpa, including P. minabilis and L. dietzi, and the high-elevation species not recorded in traps in Monte Zerpa below 3,050 m asl, C. opalinus, L. marianna, and $S$. albonotata. Three pairs of species ( $P$. minabilis and P. montagna, L. obsoleta and L. dietzi, and C. chelonis and C. pax) recorded in Monte Zerpa and replacing each other in elevation are also found in El Baho. Lymanopoda dietzi and L. obsoleta overlap at 2,600-2,750 in Monte Zerpa and come into contact at $2,400-2,450 \mathrm{~m}$ asl in El Baho. Corades pax and $C$. chelonis overlap in Monte Zerpa at 2,450-2,700 $\mathrm{m}$ asl and at 2,400-2,500 $\mathrm{m}$ asl in El Baho. Pedaliodes minabilis and $P$. montagna overlap at 2,5502,800 in Monte Zerpa and 2,400-2,600 in El Baho. Altitudinal ranges of $P$. minabilis and $P$. ornata in Monte

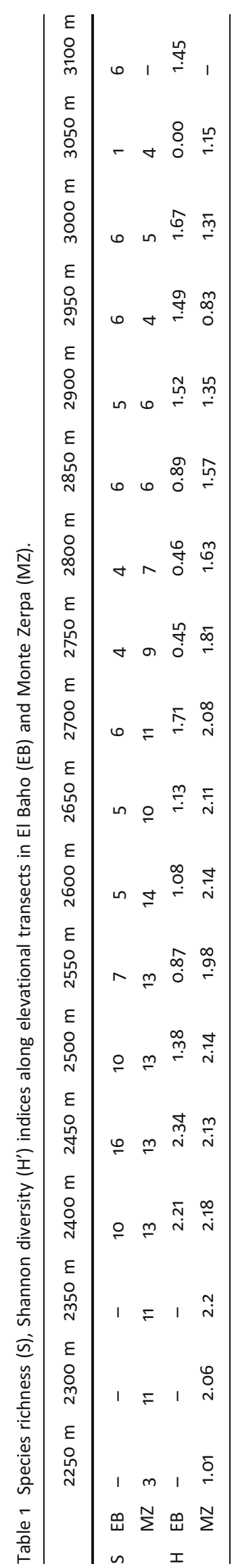


Table 2 Overall diversity indices in Monte Zerpa and El Baho.

\begin{tabular}{llllll}
\hline & Fisher alpha & Shannon & Berger-Parker & Simpson & Evenness \\
\hline Monte Zerpa & 3.52 & 2.45 & 0.16 & 0.11 & 0.57 \\
El Baho & 4.6 & 1.88 & 0.02 & 0.31 & 0.42 \\
\hline
\end{tabular}

Zerpa overlap and show a strong positive correlation $\left(S_{\text {corr }}=0.86 ; P<0.001\right.$ ) (Fig 3).

\section{Discussion}

Species composition in Monte Zerpa and El Baho is almost identical, which agrees with predictions based on

Table 3 Percentages of species in the samples in Monte Zerpa and El Baho (collected in baited traps along altitudinal transects), species with more than $10 \%$ in the sample are highlighted in bold.

\begin{tabular}{|c|c|c|}
\hline & El Baho & Monte Zerpa \\
\hline Cheimas opalinus & $1.8 \%$ & $-{ }^{a}$ \\
\hline Corades chelonis & $1.3 \%$ & $5.3 \%$ \\
\hline Corades sp. & $0.9 \%$ & $-^{a}$ \\
\hline Corades medeba & $0.6 \%$ & $0.5 \%$ \\
\hline Corades panonia & $-^{c}$ & $0.9 \%$ \\
\hline Corades pax & $11.4 \%$ & $2.4 \%$ \\
\hline Eretris porphyria & $1.5 \%$ & $15.5 \%$ \\
\hline Lasiophila zapatoza & $0.7 \%$ & $2.8 \%$ \\
\hline Lymanopoda albocincta & $-^{c}$ & $1.0 \%$ \\
\hline Lymanopoda dietzi & $3.5 \%$ & $3.4 \%$ \\
\hline Lymanopoda marianna & $0.6 \%$ & $-^{a}$ \\
\hline Lymanopoda obsoleta & $0.4 \%$ & $4.2 \%$ \\
\hline Manerebia franciscae & $0.6 \%$ & $-{ }^{\mathrm{e}}$ \\
\hline Mygona irmina & $1.1 \%$ & $1.7 \%$ \\
\hline Pedaliodes fumaria & $-^{c}$ & $0.1 \%$ \\
\hline Pedaliodes japhleta & $0.4 \%$ & $6.2 \%$ \\
\hline Pedaliodes jephtha & $-^{d}$ & $0.1 \%$ \\
\hline Pedaliodes minabilis & $53.4 \%$ & $14.1 \%$ \\
\hline Pedaliodes montagna & $7.0 \%$ & $17.0 \%$ \\
\hline Pedaliodes ornata & - & $10.4 \%$ \\
\hline Pedaliodes panyasis & $2.0 \%$ & $0.5 \%$ \\
\hline Pedaliodes plotina & $2.8 \%$ & $-{ }^{\mathrm{b}}$ \\
\hline Pedaliodes polla & $1.8 \%$ & $0.3 \%$ \\
\hline Pronophila epidipnis & $4.4 \%$ & $3.2 \%$ \\
\hline Pronophila unifasciata & $0.2 \%$ & $-{ }^{b}$ \\
\hline Steroma bega & $2.2 \%$ & $10.3 \%$ \\
\hline Steromapedaliodes albonotata & $1.5 \%$ & $--^{a}$ \\
\hline
\end{tabular}

${ }^{\text {a }}$ Collected in hand net above 3,050 $\mathrm{m}$ asl.

${ }^{\mathrm{b}}$ Collected in hand net below 2,250 $\mathrm{m}$ asl.

${ }^{\mathrm{c}}$ Collected in hand net below 2,400 $\mathrm{m}$ asl.

${ }^{\mathrm{d}}$ Collected in hand net at 2,550 $\mathrm{m}$ asl.

${ }^{\mathrm{e}}$ Collected in hand net at $2,600 \mathrm{~m}$ asl. geographical proximity of the two sites and the knowledge of distribution patterns of Pronophilina in the $\mathrm{CM}$. The only difference between the faunas is the absence of $P$. ornata in El Baho. Pedaliodes ornata is an important absentee in EI Baho considering that it is one of five co-dominant species in the closely situated Monte Zerpa. Consequently, the assemblages of Pronophilina in El Baho and Monte Zerpa are considerably different structurally and also in the altitudinal distribution patterns of individuals species.

Structurally, the sample in El Baho is unlike other studies of Pronophilina in that one species, $P$. minabilis, accounts for more than half of all specimens. The sample in Monte Zerpa is much more typical with no single species domination and five co-dominant species representing together over $60 \%$ of all specimens (Pyrcz \& Wojtusiak 1999, 2002, Pyrcz 2004, Pyrcz et al 2009b, Mahecha Jimenez et al 2011). The models of species abundance show best fit for broken stick model for Monte Zerpa, which agrees with the assumption that it describes the assemblages with no single species dominance and high evenness. The low evenness in El Baho and the overwhelming dominance of one species could be interpreted as the sign of disturbed ecosystem.

It is unlikely that $P$. ornata has never occurred in El Baho because of its present-day distribution south and north of the Santo Domingo valley and because it is the only species of nearly 40 species of Pronophilina in the CM with such a disjunct distribution. The hypothesis that $P$. ornata went extinct in El Baho could be due to at least four major extrinsic factors: habitat loss, mass dying-off of host plants, selective pressure, or competitive exclusion. None of these can be tested at present, but their plausibility can be evaluated. Climate shift, such as dry or/and colder periods in the Pleistocene and Holocene widely documented for the CM (Schubert \& Vivas 1993), may cause local disappearance of cloud forests and cause changes in abundance or even lead to the extinction of species. It is also known that mass blooming and simultaneous dying out of Chusquea (Poaceae) bamboos over large portions of land, occurring every 10-40 years (Judziewicz et al 1999), may affect the abundance and distribution of Pronophilina (DeVries 1987). We observed such a dying out on several occasions in the Ecuadorian, Peruvian, and Venezuelan Andes (unpublished). Both phenomena act, however, non-selectively on all the species associated within a given habitat. They would therefore almost certainly have driven the extinction of all or at least some of the species 





Table 5 Number of species along elevational transects per classes of abundances.

\begin{tabular}{lllllll}
\hline & $0.1-3 \%$ & $3.1-6 \%$ & $6.1-12 \%$ & $12.1-24 \%$ & $24.1-48 \%$ & $>48 \%$ \\
\hline El Baho & 17 & 2 & 2 & 0 & 0 & 1 \\
Monte Zerpa & 10 & 4 & 3 & 3 & 0 & 0 \\
\hline
\end{tabular}

their mating chances (Davies 1978, Thornhill \& Alcock 1983). However, competition for space between males of Pedaliodes was not observed (Pyrcz 2004). It is worth to point out that there are few species of Pedaliodes, up to four, in the uppermost cloud forests in the CM. Elsewhere in the Andes, up to 20 species coexist within the same elevational band, meaning more complex interspecific interactions, and, perhaps, also a greater carrying capacity in such region (Pyrcz \& Wojtusiak 1999, Pyrcz 2004). Interspecific competition increases with increasing phenotypic similarity and finally equals infraspecific competition, which is the highest value of the competition coefficient (Rodríguez 2001). Markedly different color patterns contribute to the phenotypic dissimilarity of $P$. ornata and $P$. minabilis, consequently to their lower competition value. In the light of the above, competitive exclusion between two species of Pedaliodes seen from the traditional perspective is unlikely and remains a theoretical challenge. Notwithstanding, possible extinction of $P$. ornata in El Baho could have an important role in shaping the local Pronophilina assemblage structure by breaking a balanced two species co-domination at higher elevations and enabling $P$. minabilis to occupy its ecological niche.

Pyrcz \& Wojtusiak (2002) pointed out that in Monte Zerpa three pairs of closely related species have mutually exclusive distributions: P. montagna and P. minabilis, L. dietzi and $L$. obsoleta, and Corades chelonis and C. pax. All of them also occur in El Baho and replace each other in elevation, although, statistically, this cannot be demonstrated because the sample is not numerous enough. Signal jamming theory rests on the fact that most butterflies, and certainly those belonging to the subfamily Satyrinae (Braby \& New 1988), first locate their mates visually and then use contact pheromones once courtship has ensued (Rutowski 1997).

If two species are phenotypically similar (colors, size, flight pattern, etc.) and have overlapping ranges, individuals of one species may falsely identify the other species as a potential mate. This leads to fruitless interspecific interactions involving pursuit, courtship, and consequently to time and energy loss. Such interactions can be frequently observed in nature. In the overlapping zone, the chances of meeting an individual of its own species $(p)$ can be expressed by the simple equation: $p=a 1 / a 2+a 1$, where $a 1$ and $a 2$ are abundances of parapatric species. At the abundance equilibrium, the point where two species occur at equal numbers, $p=1 / 2$. The $p$ coefficient decreases with the distance from the equilibrium point, and interspecific interactions resulting in time and energy loss are more frequent, whereas the chances of meeting a conspecific, and successful mating are fewer. Hence, individual fitness is lower. Thus, the occurrence of individuals of one species is a buffer for the spreading of non-conspecifics and extending their species range. The two species exert on each other a dynamic, demographic
Fig 3 Altitudinal distribution patterns of three pairs of parapatric species in Monte Zerpa $(M Z)$ and El Baho $(E B)$. Box and whiskers plot with median, lower, and upper quartile, minimum and maximum and outside values of altitude range.

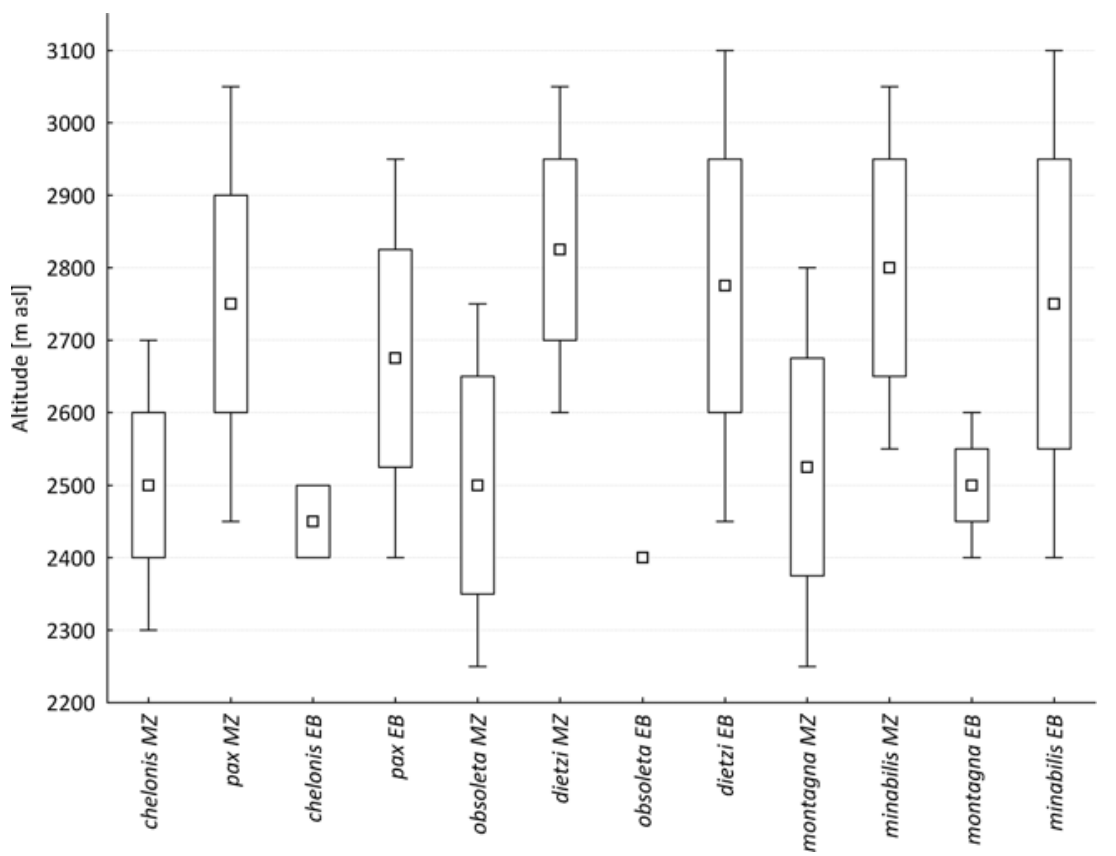


pressure. Altitudinal distribution patterns may shift when the balance of abundance is disturbed, for example, by the extinction of species or the dying-out of host plants in a given elevational band. In fact, in all three cases of parapatric species their overlapping zone in El Baho is situated some $200-250 \mathrm{~m}$ lower than in Monte Zerpa. We assume that this mechanism may occur in case of parapatric species, whose behavioral sexual isolation mechanisms are imperfect, rather than among sympatric species with widely overlapping ranges. Pyrcz \& Wojtusiak (2002) put out a case strongly suggesting that closely related parapatric species have an effect on the width of the elevational range of each other. Corades chelonis occurs up to 2,500-2,700 $\mathrm{m}$ asl throughout the $\mathrm{CM}$ and is replaced at higher elevations by $C$. pax. In the neighboring El Tamá massif, where neither $C$. pax nor any other closely related species exists, $C$. chelonis occurs to timberline at 3,000-3,100 $\mathrm{m}$ asl. In the same range, $L$. obsoleta occurs up to $2,400-2,600 \mathrm{~m}$ asl and is replaced at higher elevations by its sister species Lymanopoda lecromi Pyrcz \& Viloria (Pyrcz \& Viloria 2007, Casner \& Pyrcz 2010, Pyrcz et al 2010). However, in the Bolivian Yungas, where L. obsoleta has no upper parapatric ally, it occurs at least up to $3,000 \mathrm{~m}$ asl, therefore near timberline. In northern Peru, Corades cistene Hewitson occurs to at least 3,200 $\mathrm{m}$ asl (Pyrcz 2004), whereas in south-east Ecuador, where its range overlaps with that of its sister species Corades dymantis Thieme, it occurs only up to $2,400-2,500 \mathrm{~m}$ asl and is replaced at higher elevations by the latter species (Pyrcz 2010). Spatial interference is a mechanism which may apply to many other cases of closely related species of butterflies distributed parapatrically in adjacent altitudinal bands and indeed to other taxa (Shapiro 1992). This hypothesis needs to be tested, although securing direct experimental evidence bearing on the problem will be exceedingly difficult.

\begin{abstract}
Acknowledgments The authors wish to thank Pierre Boyer (Le Puy Sainte Réparade) and Janusz Wojtusiak (Kraków) who largely assisted in the field work in El Baho; Kayce Casner and Arthur Shapiro (Davis, USA) for the critical reading and useful comments on the manuscript. First author's field work in Venezuela in 2006 and 2007 was supported by grants of the Institute of Zoology of the Jagiellonian University DS/BiNOZ/IZ/778-2006/2007.
\end{abstract}

Open Access This article is distributed under the terms of the Creative Commons Attribution License which permits any use, distribution, and reproduction in any medium, provided the original author(s) and the source are credited.

\section{References}

Adams M, Bernard G (1981) Pronophiline butterflies (Satyridae) of the Cordillera de Mérida, Venezuela. Zool J Linnean Soc 71:343-372

Adams M (1985) Speciation in the pronophiline butterflies (Satyridae) of the Northern Andes. J Res Lepidoptera, Supplement no. 1, 33-49

Allen JA, Anderson KP (1984) Selection by passerine birds is antiapostatic at high prey density. Biol J Linn Soc 23:237-246
Bengtsson J (1989) Interspecific competition increases local extinction rate in a metapopulation system. Nature 340:713-715

Braby MF, New TR (1988) Population biology of adult Geitoneura klugii and Geitoneura acantha (Lepidoptera, Satyrinae) near Melbourne, Australia. Aust J Zool 36(2):141-158

Casner KL, Pyrcz TW (2010) Patterns and timing of diversification in a tropical montane butterfly genus Lymanopoda (Nymphalidae, Satyrinae). Ecography 33:251-259

Ciroz-Pérez J, Carmona MJ, Serra M (2002) Resource competition and patterns of sexual reproduction in sympatric sibling rotifer species. Oecologia 131:35-42

Davies NB (1978) Territorial defense in the speckled wood butterfly (Pararge aegeria): the resident always wins. Anim Behav 26:138-147

Denno RF, McClure MS, Ott JR (1995) Interspecific interactions in phytophagous insects: competition reexamined and resurrected. Annu Rev Entomol 40:297-332

DeVries PJ (1987) The butterflies of Costa Rica and their natural history. Papilionidae, Pieridae and Nymphalidae. I. Princeton University Press, New Jersey

Escobar F, Lobo JM, Halffter G (2005) Altitudinal variation of dung beetle (Scarabaeidae: Scarabaeinae) assemblages in the Colombian Andes. Glob Ecol Biogeogr 14:327-337

Feng W (1997) Competitive exclusion and persistence in models of resource and sexual competition. J Math Biol 35(6):683-694

Gabryś G (2000) Balaustium xerothermicum sp. nov. from Poland with remarks on all world species of the genus (Acari: Actinedida: Erythraeidae). Ann Zool 50(1):47-56

Gause GF (1934) The struggle for existence. Williams and Wilkins, Baltimore

Greeney HF, Pyrcz TW, Hualingua M, DeVries PJ, Dyer LE (2009) The natural history of Pedaliodes poesia (Hewitson, 1862) in eastern Ecuador (Lepidoptera, Satyrinae, Pronophilina). J Insect Sci 9:38

Greeney HF, Pyrcz TW, Dyer LA, Sanchez MZ (2010) The early stages and natural history of Corades medeba Hewitson, 1850 in eastern Ecuador (Lepidoptera: Nymphalidae: Satyrinae: Pronophilina). Trop Lepidoptera Res 20(1):8-13

Gröning J, Hochkirch A (2008) Reproductive interference between animal species. Q Rev Biol 83(3):257-282

Hanski I \& Niemela J (1990) Elevational distribution of dung and carrion beetles in northern Sulawesi. In: Knight WJ, Holloway JD (eds.) Insects and the rain forests of South East Asia (Wallacea). Royal Entomological Society of London, pp. 145-152

Hutchinson GE (1957) Concluding remarks. Cold Spring Harb Symp Quant Biol 22:415-427

Judziewicz EJ, Clark L, Londoño, Stern MJ (1999) American bamboos. Washington DC, Smithsonian Institution Press.

Juliano SA, Lounibos LP, O'Meara GF (2004) A field test for competitive effects of Aedes albopictus on Aedes aegypti in South Florida: differences between sites of coexistence and exclusion? Oecologia 139:583-593

Lamas G, Viloria AL, Pyrcz TW (2004) Subtribe Pronophilina. In: Lamas E (ed) Atlas of neotropical Lepidoptera, checklist: part 4A, HesperoideaPapilionoidea. Association for Tropical Lepidoptera, Gainesville

Lindström L, Alatalo RV, Lyytinen A, Mappes J (2001) Strong antiapostatic selection against novel rare aposematic prey. Proc Natl Acad Sci U S A 98(16):9181-9184

Mahecha Jimenez OJ, Dumar Rodriguez JC, Pyrcz TW (2011) Efecto de la fragmentacion del habitat sobre las comunidades de mariposas de la tribu Pronophilini a lo largo de un gradiente altitudinal and un bosque andino en Bogota (Colombia). SHILAP 39(153):117-126, 2011

Mougi A, Nishimura K (2005) Coexistence of competitive species with a stage-structured life cycle. Ecol Res 20:581-589

Peck SB, Howden HF (1984) Response of a dung beetle guild to different sizes of dung bait in a Panamanian rainforest. Biotropica 16(3):235-238 
Pyrcz TW (2004) Pronophiline butterflies of the highlands of Chachapoyas in northern Peru: faunal survey, diversity and distribution patterns (Lepidoptera, Nymphalidae, Satyrinae). Genus 15 (4):455-622

Pyrcz TW (2007) Description of a new pronophiline butterfly from the Venezuelan Cordillera de Mérida previously known as Pedaliodes ferratilis form luteocosta Adams \& Bernard with data on its altitudinal distribution (Lepidoptera: Nymphalidae: Satyrinae). Genus 19 (1):125-134

Pyrcz TW (2010) Wybrane zagadnienia z taksonomii, zoogeografii $\mathrm{i}$ ewolucji faun górskich na przykładzie grupy modelowej motyli z plemienia Pronophilini (Nymphalidae). Wydawnictwo Mantis, Olsztyn, p 245

Pyrcz TW, Viloria AL (2007) Erebiine and pronophiline butterflies of the Serranía del Tamá, Venezuela-Colombia border. Trop Lepidoptera 15(1-2):18-52

Pyrcz TW, Viloria AL (2009) Systematics, zoogeography and bionomics of high Andean pedaliodines, part 11: a new subspecies of Pedaliodes ornata Grose-Smith \& Kirby in the Venezuelan Cordillera de Merida (Lepidoptera: Nymphalidae: Satyrinae). Genus 20(1):13-22

Pyrcz TW, Casner K, Wojtusiak J (2009a) Polytypic species of satyrine butterflies in the subpáramo and páramo of the Venezuelan Cordillera de Merida, part 1: Lymanopoda marianna Staudinger. Genus 20(3):507-532

Pyrcz TW, Wojtusiak J, Garlacz R (2009b) Diversity and altitudinal distribution pattern of Pronophilina butterflies in north-western Ecuador (Nymphalidae: Satyrinae). Neotrop Entomol 38(6):716-726

Pyrcz TW, Viloria AL, Boyer P (2010) The obsoleta clade of the genus Lymanopoda Westwood (Lepidoptera, Nymphalidae: Satyrinae). Folia Entomol Hung 71:161-195
Pyrcz TW, Wojtusiak J (1999) Mariposas de la Pronophilini de la Reserva Forestal Tambito, Cordillera Occidental, Colombia. Segunda parte. Patrones de distribución altitudinal. SHILAP 27 (106):203-213

Pyrcz TW, Wojtusiak J (2002) The vertical distribution of pronophiline butterflies (Nymphalidae, Satyrinae) along a elevational transect in Monte Zerpa (Cordillera de Mérida, Venezuela) with remarks on their diversity and parapatric distribution. Glob Ecol Biogeogr 11:211-221

Reis SF, von Zuben CJ, Godoy WAC (1999) Larval aggregation and competition for food in experimental populations of Chrysomya putoria (Wied.) and Cochliomyia macellaria (F.) (Dipt., Calliphoridae). J Appl Entomol 123(8):485-489

Rodríguez J (2001) Ecología. Pirámide, Madrid

Rutowski RL (1997) Sexual dimorphism, mating systems and ecology in butterflies. In: Choe JC, Crespi BJ (eds) The evolution of mating systems in insects and arachnids. Cambridge University Press, Cambridge

Schubert C, Vivas L (1993) El Cuaternario de la Cordillera de Mérida, Andes venezolanos. Mérida. Universidad de Los Andes/Fundación Polar

Shapiro AM (1992) Twenty years of fluctuating parapatry and the question of competitive exclusion in the butterflies Pontia occidentalis and P. protodice (Lepidoptera: Pieridae). J N Y Entomol Soc 100:311-319

Thornhill R, Alcock J (1983) The evolution of insect mating systems. Harvard University Press, Cambridge

Veillon JP (1989) Los bosques naturales de Venezuela, Parte I. Mérida, Universidad de Los Andes, El medio ambiente

Viloria AL, Pyrcz TW, Wojtusiak J, Ferrer-Paris JR, Beccaloni GW, Sattler K, Lees DC (2003) A brachypterous butterfly? Proc R Soc Lond B 270(suppl):S21-S24 